[To Appear in European Investment Law and Arbitration Review 2019]

\title{
The Uneasy Relationship between Intra-EU Investment Tribunals and the Court of Justice's Achmea Judgment
}

\author{
Szilárd Gáspár-Szilágyi and Maxim Usynin*
}

\begin{abstract}
This paper focuses on the ways in which investment tribunals constituted under intra-EU BITs and the Energy Charter Treaty (in an intra-EU dispute) have reacted to the Court of Justice's Achmea judgment of 6 March 2018. The first part of the paper maps out the existing intra-EU arbitrations in which the issues arising from Achmea appear in one form or another. We then take a critical look at how the disputing parties have used Achmea in their argumentation and how the investment tribunals have dismissed these arguments and upheld their jurisdiction. The second part of the paper is analytical. When the tribunals uphold their jurisdiction and decide on the merits, they knowingly deliver an award, which is unenforceable in the Respondent State and the entirety of the EU. By drawing parallels with decisions rendered by other international tribunals, we argue that the rendering of potentially unenforceable awards is not specific to intra-EU investment disputes. We then look at why international tribunals render potentially unenforceable awards. The third part of the paper presents several suggestions of how intra-EU investment tribunals should tackle the Achmea conundrum, either by declining their jurisdiction pursuant to judicial comity or upholding their jurisdiction but dismissing the cases as inadmissible.
\end{abstract}




\section{Introduction}

The EU's exercise of its post-Lisbon competences over foreign direct investment (FDI) has been anything but smooth. ${ }^{1}$ The difficult task of solving some of the major challenges faced by this new policy area reverted to the Court of Justice of the European Union (Court of Justice). Beyond their effects within the EU legal order, the rulings of the Court have very important external policy and legal implications. For example, in Opinion $2 / 15^{2}$, the Court of Justice clarified the EU and EU Member State competences over the EU's new generation of free trade and investment agreements, which resulted in the splitting of the EU-Singapore Free Trade Agreement(FTA) into separate trade and investment agreements. ${ }^{3}$ By doing so, the Court pointed out a path different than the growing trend of combining trade and investment chapters under one treaty roof. ${ }^{4}$

Furthermore, in Achmea ${ }^{5}$ the Court held that investor-state arbitration clauses under international agreements between EU Member States, "such as" the one under the NetherlandsSlovakia Bilateral Investment Treaty (BIT), are precluded by EU law. This judgment will result in the termination of almost 200 intra-EU Bilateral Investment Treaties (BITs) ${ }^{6}$ and the non-enforcement of ITA awards ${ }^{7}$ rendered under them within the EU. Similarly, the indeterminate wording of "such as" raises the question whether Achmea applies to intra-EU disputes under the Energy Charter Treaty (ECT), which would make the awards of intra-EU tribunals constituted under it unenforceable within the EU legal order. Whilst the European Commission (Commission) has

* Szilárd is a Postdoctoral Fellow at PluriCourts, University of Oslo [szilard.gaspar-szilagyi@jus.uio.no]. Max is a Doctoral Fellow at CEVIA, University of Copenhagen [maksim.usynin@jur.ku.dk]. This work was partly supported by the Research Council of Norway through its Centres of Excellence funding scheme, project number 223274, and the Danish Council for Independent Research. We thank Daniel Behn (Liverpool, Oslo) for allowing us to use some of his newest dataset and we also thank the organizers of and participants to the 'EU Law, Trade Agreements, and Dispute Resolution Mechanisms: Contemporary Challenges' Conference (Kings College, 21-22 March 2019) for their constructive comments.

1 See Sz Gáspár-Szilágyi, 'Quo Vadis EU Investment Law and Policy? The Shaky Path towards the International Promotion of EU Rules’ [2018] 23(2) European Foreign Affairs Review 167.

CJEU Opinion 2/15 (EU-Singapore FTA), ECLI:EU:C:2017:376.

European Commission, 'EU-Singapore Trade and Investment Agreements' (Authentic Texts as of April 2018) <http://trade.ec.europa.eu/doclib/press/index.cfm?id=961> accessed on 1 June 2019.

$4 \quad$ M Usynin and Sz Gáspár-Szilágyi, 'The Growing Tendency of Including Investment Chapters in PTAs' in F Amtenbrink et al (eds) Netherlands Yearbook of International Law 17 [2018] vol 48.

$5 \quad$ CJEU Slovak Republic v Achmea BV, ECLI:EU:C:2018:158.

6 Declaration of the Member States of 15 January 2019 on the Legal Consequences of the Achmea Judgment and on Investment Protection, <https://ec.europa.eu/info/publications/190117-bilateral-investmenttreaties_en> accessed on 1 June 2019.

$7 \quad$ German Federal Court of Justice (BGH), Decision I ZB 2/15 in which it set aside the arbitral award of 22 million euros in favour of Achmea $B V$, following the Court's judgment. 
long advocated for the inapplicability of such awards due to the ECT's "implicit disconnection clause", 8 the Court of Justice has yet to explicitly back this argument.

This year, everyone was anxiously awaiting the outcome of Opinion $1 / 17^{9}$ - requested by Belgium under the insistencies of Wallonia - and whether the Investment Court System (ICS) in the agreement with Canada (CETA) is compatible with EU law. The Court of Justice has recently concluded that the ICS in CETA is compatible with EU law. Therefore, this opinion will not only affect the entry into force and conclusion of the EU's trade and investment agreements with Canada, Singapore, Vietnam and Mexico, but it will have broader implications for the multilateral investorstate dispute settlement (ISDS) reform process ${ }^{10}$ and the EU's investment policy. Opinion $1 / 17$ goes beyond the scope of this paper and will therefore not be discussed.

Achmea and Opinion 1/17 are not singular cases, but form part of an established and ever-expanding case law of the Court of Justice on the relationship between extra-EU dispute settlement mechanisms (DSMs) and EU law. ${ }^{11}$ The Achmea judgment also has important practical implications for pending and future arbitral cases in an intra-EU context.

This paper leaves behind the discussion on how Achmea fits into the Court's existing case law on the autonomy of EU law and extra-EU DSMs ${ }^{12}$ and instead focuses on the investment arbitration perspective; more specifically, the ways in which investment-treaty arbitral (ITA) tribunals have reacted to the Achmea ruling. Furthermore, we focus on how ITA tribunals can ameliorate the tensions between EU law and investment law, and not on how the political actors are to solve these issues, either by terminating or amending intra-EU BITs and the ECT.

8 See, for example, Charanne BV and Construction Investments SARL v The Kingdom of Spain, SCC Case No 062/2012, Final Award, 21 January 2016, paras 223, 252, 433-439; RREEF Infrastructure (GP) Limited and RREEF Pan-European Infrastructure Two Lux Sà r.l v Kingdom of Spain, ICSID Case No ARB/13/30, Decision on Jurisdiction, 6 June 2016, paras 67, 81-87.

$9 \quad$ CJEU, Opinion 1/17 (CETA Investment Court) ECLI:EU:C:2019:341.

10 UNCITRAL, Working Group III, Investor-State Dispute Settlement Reform <http://www.uncitral.org/uncitral/ en/commission/working_groups/3Investor_State.html> accessed on 1 June 2019.

11 CJEU Opinion 1/91 (EEA I) ECLI:EU:C:1991:49; Opinion 1/92 (EEA II), ECLI:EU:C:1992:189; Opinion 1/00 ECLI:EU:C:2002:231; Opinion 1/09 (European Patent Court) ECLI:EU:C:2011:123; Opinion 2/13 (Accession to the ECHR) ECLI:EU:C:2014:2454.

12 See C Contartese and M Andenas, 'EU autonomy and investor-state dispute settlement under inter se agreements between EU Member States: Achmea' [2019] 56 CMLR 157; I J D H Pohl, 'Intra-EU Investment Arbitration after the Achmea Case: Legal Autonomy Bounded by Mutual Trust?' [2018] 14(4) European Constitutional Law Review 767; Sz Gáspár-Szilágyi, 'It is Not Just About Investor-State Arbitration. A Look at Case C-284/16, Achmea BV’ [2018] 3(1) European Papers 357. 
The first part of the paper is descriptive and maps out the existing intra-EU arbitrations in which issues arising from Achmea appear in one form or another. We have covered cases that were pending when the Court delivered Achmea (which could either be pending or concluded at the moment of writing) and cases that were initiated after the Court's ruling. This includes cases initiated under both intra-EU BITs and the ECT, if the latter concerns disputes between EU Member States. Furthermore, the analysis does not focus on domestic enforcement proceedings after the awards were delivered (although some are briefly mentioned) or proceedings that involve the annulment or rectification of awards.

Based on the empirical data, we take a critical look at how the disputing parties have used Achmea in their argumentation. Our hypothesis is that the respondent EU Member States raise Achmea in the jurisdictional phase, as an argument against the tribunals having jurisdiction. It is also highly likely that the Commission intervenes as an amicus curiae or a non-disputing party. We then look at how the tribunals have reacted to the Achmea related arguments of the disputing parties. Looking at pre-Achmea arbitral cases in which the Respondent Member States unsuccessfully relied on EU law to argue against the tribunals' jurisdiction, we expect that the arbitral tribunals will dismiss the Achmea argument based on the ground that they derive their jurisdiction from international investment agreements, and not from EU law. We also take account of whether arbitral tribunals have come up with novel reasons for dismissing the relevance of EU law to their jurisdiction or whether they are more inclined to follow the path established by earlier tribunals.

The second part of the paper is analytical. If the tribunals uphold their jurisdiction and decide on the merits, they will knowingly deliver an award which is unenforceable in the Respondent State and the entirety of the EU. Drawing parallels with disputes rendered by other international tribunals, such as the South China Sea arbitration ${ }^{13}$ and the Arctic Sunrise dispute, ${ }^{14}$ we argue that the upholding of jurisdiction when tribunals render potentially unenforceable awards is not specific to intra-EU investment disputes. Then we discuss why might international tribunals uphold their jurisdiction when they render potentially unenforceable awards or decisions.

13 PCA, The South China Sea Arbitration (The Republic of Philippines $v$ The People's Republic of China), Final Award, 12 July 2016.

$14 \quad$ ITLOS, The Arctic Sunrise Case (Kingdom of the Netherlands v Russian Federation) Case No 22. 
In the third part of the paper we discuss various suggestions on how intra-EU investment tribunals could tackle the Achmea conundrum, either by declining their jurisdiction pursuant to judicial comity or upholding their jurisdiction but dismissing the cases as inadmissible.

\section{Arbitral Tribunals Uphold Their Jurisdiction after Achmea as well}

In Achmea, the Court of Justice concluded that EU law - and more specifically Articles 267 and 344 TFEU - precludes ITA provisions in international agreements concluded between EU Member States, such as as the ITA provisions under the Netherlands-Slovakia BIT. Due to the Court's broad phrasing of "such as"- repeated several times in the judgment - commentators soon began to wonder whether the judgment should only apply to intra-EU BITs or to other international agreements as well, such as the ECT, or even BITs between EU Member States and third countries. ${ }^{15}$ In this section, we take the view that the wording used in Achmea is broad enough to make the judgment applicable to the ECT. The use of "such as" in relation to "international agreements concluded between Member States" does not limit the application of the judgment to BITs only, but makes the judgment applicable to the ECT as well, when an EU investor brings a claim against another EU Member State (i.e. in an intra-EU setting). In such cases, the ECT functions in the same manner as an intra-EU BIT. ${ }^{16}$

As Annex 1 illustrates, at the moment of writing, there are 98 intra-EU investment arbitrations - brought under various intra-EU BITs, the ECT, or both - that were pending when Achmea was delivered or were initiated after that. Most of the cases are still pending, but in eight of them (six concluded and two pending) the tribunals have already discussed the implications of Achmea. In the following sections, we discuss how the disputing parties have relied on the Court of Justice's Achmea judgment and the ways in which the investment tribunals have reacted to these arguments. We will also provide a brief overview of the pre-Achmea cases (see Annex 2).

$15 \quad$ See $\mathrm{n} 12$.

16 For a detailed discussion of whether the Achmea judgment applies to the ECT, see Expert Declaration of Steffen Hindelang in Support of Respondent the Kingdom of Spain's Motion to Dismiss and to Deny Confirmation of Foreign Arbitral Award in USDC for the District of Columbia, Novenergia II v Kingdom of Spain, Civil Action No. 1:18-cv-1148. See also J Kleinheisterkamp, 'Investment Protection and EU Law: The Intra- and Extra-EU Dimension of the Energy Charter Treaty’ [2012] 15 JIEL 85. 


\subsection{How do the Disputing Parties Rely on Achmea?}

Raising arguments based on EU law before an arbitral tribunal is not a novelty and by now, there is a certain practice of it. ${ }^{17}$ Eastern Sugar v Czech Republic, ${ }^{18}$ initiated under the Czech-Netherlands BIT and decided in 2004, was the first case in which the issue arose whether or not an investment tribunal should take into account arguments based on EU law in the jurisdictional phase of the dispute. The Commission sent a letter to the Czech Republic, based on which the Respondent argued that the Tribunal lacked jurisdiction as the EU Treaties had superseded the BIT after the accession of the Czech Republic to the EU. ${ }^{19}$ The Tribunal rejected these arguments and upheld its jurisdiction. It held that there was no implicit or explicit termination of the intra-EU BIT when the Czech Republic acceded to the EU. ${ }^{20}$

The years that followed saw a string of cases (see Annex 2) initiated under intra-EU BITs or under the ECT in an intra-EU context, in which the Respondent Member State and the Commission - as amicus or non-disputing party - raised objections based on EU law against the jurisdiction of the arbitral tribunals. Among others, the Respondents and the Commission based their arguments on the primacy and autonomy of EU law, ${ }^{21}$ as well as EU state aid rules. ${ }^{22}$ In the recent $A 11 Y \mathrm{v}$ Czech Republic, commenced under the UK-Czech BIT prior to Achmea, the Czech Republic once again argued that EU law had superseded the BIT following its accession to the EU, whilst the Claimant objected to this argument based on past $\operatorname{cases}^{23}$ dealing with this issue and pursuant to Articles 59 and 65 of the Vienna Convention on the Law of Treaties (VCLT). ${ }^{24}$ The Tribunal, just as every other tribunal before $i t,{ }^{25}$ rejected these EU law objections and upheld its jurisdiction,

$17 \quad$ See C Contartese, 'EU law as Applicable Law in International Disputes and its Procedural Implications', in M Andenas et al (eds) The EU External Action in International Economic Law. Recent Trends and Developments (Asser Press/Springer, forthcoming).

18 Eastern Sugar v Czech Republic, SCC 088/2004, Partial Award, 27 March 2007.

19 Ibid., para 119.

20 Ibid., paras 142-180.

21 See, for example, Euram v Slovakia, PCA 2010-17, First Award on Jurisdiction, 22 October 2012.

22 See, for example, Micula v Romania, ICSID ARB/05/20, Final Award, 11 December 2013.

23 Claimant refers to RREEF Infrastructure (G.P.) Limited and RREEF Pan-European Infrastructure Two Lux S.a.r.1. v Kingdom of Spain, ICSID Case No ARB/13/30, Decision on Jurisdiction, 6 June 2016, CL-130, para 89 "the Tribunal underlines that in all published or known investment treaty cases in which the intra-EU objection has been invoked by the Respondent, it has been rejected".

24 Al1Y Ltd v Czech Republic, ICSID Case No UNCT/15/1, Decision on Jurisdiction, 9 February 2017, paras 152-169.

25 The Tribunal referencing Micula v Romania (n 22) RL-68, para 321; Eastern Sugar v Czech Republic (n 18) para 167; Achmea BV v The Slovak Republic, UNCITRAL, PCA Case No. 2008-13 (formerly Eureko BV v The Slovak Republic), Award on Jurisdiction, Arbitrability and Suspension, 26 October 2010, RL-43, paras 244-252; Jan Oostergetel and Theodora Laurentius $v$ The Slovak Republic, UNCITRAL, Decision on Jurisdiction, 30 April 2010, CL-94, paras 80-85; Euram v Slovakia (n 21), paras 186-210. 
arguing that according to both parties to the BIT, the agreement was still in force. Whilst the Tribunal in this case, for the sake of judicial economy, handled the EU law objection in a laconic fashion, other tribunals have spent considerably more time on this matter, even going so far as to interpret EU law, such as when the Tribunal in Euram $v$ Slovakia interpreted Article 344 TFEU as not applying to intra-EU BITs. ${ }^{26}$

Thus, one would expect that following Achmea, the Respondent Member States and the intervening Commission would continue objecting to the jurisdiction of the tribunals. The difference, however, compared to the aforementioned cases is that now the arguments have a lot more solid backing: the judgment of the Court of Justice. It is one thing for a member of a regional organization and its 'executive' body to argue that they view the law of the regional organization as precluding the jurisdiction of the arbitral tribunals. It is a completely different situation when the 'constitutional court' of that organization - which has the ultimate authority to render binding interpretations of the organization's law - holds that the jurisdiction of said arbitral tribunals is incompatible with the law of the organization.

The post-Achmea cases have followed the same pattern as the pre-Achmea cases with the Respondent Member States challenging the tribunals' jurisdiction on the basis of EU law and Achmea, while the investors use the judgment for the opposite reason. Every now and then, the Commission intervenes as an amicus. For example, in both Masdar v Spain and UP and CD v Hungary, initiated under the ECT and the France-Hungary BIT respectively, the Respondents requested the tribunals to interpret the ITA provisions in line with EU law, while the Claimants argued that Achmea was not relevant for the Tribunal's jurisdiction. ${ }^{27}$ In the pending ECT case of Vattenfall v Germany, the arguments differed slightly. The Respondent State and the intervening Commission argued that EU law was part of the applicable law; thus, Achmea was applicable to the ECT. The Claimant, however, argued that EU law was not part of international law and the applicable law, and thus Achmea was not applicable to the ECT. ${ }^{28}$

The Respondents' reliance on a ruling of the Court of Justice is meant to raise the importance of the issue and send a signal to the arbitral tribunals that not only the political actors of the EU, but

$26 \quad$ Euram v Slovakia (n 21) paras 248-267.

27 Masdar v Spain, ICSID Case No ARB/14/1, Award, 16 May 2018; UP and DC v Hungary, ICSID Case No ARB/13/35, Award, 9 October 2018.

28 Vattenfall v Germany, ICSID Case No ARB/12/12, Decision on Achmea Issue, 31 August 2018. 
the main judicial body also backs a certain interpretation. The next section, however, illustrates how the tribunals were not persuaded by the new arguments based on Achmea.

\subsection{How Do the Tribunals Respond to Achmea?}

As discussed, in the pre-Achmea cases, the arbitral tribunals always upheld their jurisdiction whenever the Commission or the Respondent objected to it on EU law grounds. The most commonly used argument was that the tribunals derive their jurisdiction from international agreements and not EU law, and that the EU Treaties did not supersede the intra-EU BITs. Thus, one would expect tribunals to use the same arguments in the post-Achmea cases as well. However, there is also the issue of Achmea's applicability to the ECT. It can be expected that some ECT tribunals might argue that Achmea is not applicable to them as it is only applicable to intra-EU BITs. However, some tribunals could show greater deference to the ruling of the Court of Justice as opposed to the Commission's objections. Whilst the Commission is charged with "oversee[ing] the application of Union law", ${ }^{29}$ the Court of Justice is the institution that "ensure[s] that in the interpretation and application of the [EU] Treaties the law is observed" 30 and it is the only institution that can provide binding interpretations of EU law. ${ }^{31}$

This section classifies the tribunals' responses into two groups. The first group comprises the cases where the tribunals agreed to dwell into the jurisdictional effects of Achmea and eventually rejected Achmea's applicability to the dispute. The second group comprises the cases where the tribunals refused to consider Achmea as part of the jurisdictional argument, citing various procedural impediments. Such procedural impediments are worth evaluating against any preclusive effects Achmea may have on the tribunals' jurisdiction, especially when it comes to intra-EU BIT cases. Indeed, one may question to what extent a late filing of a jurisdictional objection should lead to the same result as a timely filing, assuming that the latter would ordinarily result in a termination of the proceedings.

Before proceeding to the analysis, a further delimitation deserves mention. This paper concerns the effects and responses to Achmea, excluding cases where the parties and the tribunals have ignored Achmea as part of the legal argument. An example is the afore-mentioned A11Yv

29 Treaty on the European Union (TEU), Article 17(1).

30 TEU, Article 19(1).

31 Opinion 2/13 (Accession to the ECHR) ECLI:EU:C:2014:2454, para 242. 
Czech Republic arbitration in which, even though the Respondent raised EU law objections to the Tribunal's jurisdiction, it did not mention the Achmea case that was pending at that point in time. The Tribunal decided on the jurisdiction prior to the Achmea judgment, but rendered its final award after Achmea, without mentioning the judgment.. ${ }^{32}$ Interestingly, the Tribunal discussed the termination of intra-EU BITs in the final award as well, not just in the decision on jurisdiction, and concluded that both parties to the BIT in question treated it as still active and valid. ${ }^{33}$ This suggests that tribunals will not tackle the Achmea issue proprio motu, but the disputing parties must actively raise it. In addition, tribunals have been continuously critical to the 'automatic termination of BITs by accession to the EU' argument, which needs to be supplemented by some active measures from EU Member States.

\subsubsection{Tribunals that Admit Achmea as a Jurisdictional Objection}

EU Member States have relied on Achmea as a jurisdictional objection. An objection must nevertheless follow the procedural timeline of the dispute and has to be addressed together with other jurisdictional arguments. Alternatively, if the proceedings have advanced beyond the jurisdictional stage, States may request the consideration of Achmea beyond the procedural timeline as a new fact or circumstance. This section reviews the responses of tribunals which have agreed to consider Achmea as a jurisdictional objection within or after the procedural timeline for submitting such objections.

\subsubsection{Achmea Does Not Apply to the ECT and Other Multilateral Treaties}

Some tribunals have decided that Achmea does not have a preclusive effect on intra-EU arbitrations under the ECT. This argument is gaining traction and has come to be adopted in several intra-EU disputes initiated pursuant to the ECT.

One example is the Masdar v Spain award rendered under the ECT. Similarly to over three dozen other cases, the claim arose following the change in the regulatory framework of investments in solar energy in Spain. When the Court of Justice delivered the Achmea judgment, the Tribunal had already closed the proceedings. ${ }^{34}$ Nevertheless, the Respondent applied for the re-opening of

A11Y LTD v Czech Republic, ICSID Case No UNCT/15/1, Award, 29 June 2018.

Ibid., paras 174-178.

Masdar Solar \& Wind Cooperatief UA v Kingdom of Spain, ICSID Case No ARB/14/1, Award, 16 May 2018 , para 80 . 
the proceedings under Article 38(2) of the ICSID Convention Arbitration Rules, which allows for the re-opening of proceedings under exceptional circumstances "on the ground that new evidence is forthcoming of such a nature as to constitute a decisive factor, or that there is a vital need for clarification on certain specific points". 35

In its request, the Respondent stipulated that Achmea referred to international agreements in general, including the ECT, which would deprive the Tribunal of jurisdiction. ${ }^{36}$ The Tribunal rejected the argument on two grounds. Firstly, the Achmea judgment concerned a BIT between the Netherlands and the Czech and Slovak Federal Republic. Therefore, it "[could not] be applied to multilateral treaties, such as the ECT, to which the EU itself is a party." 37 Secondly, with regard to the ECT, the Tribunal referred to the Opinion of Advocate General Wathelet who had not seen the "slightest suspicion that it might be incompatible [with the TEU and TFEU]." 38 The Tribunal then referred to the silence of the Court of Justice on the matter of the ECT's compatibility with EU law and adopted the position of the Advocate General. ${ }^{39}$ One may add that the Tribunal's reliance on the latter brings back the questions of power distribution and authoritative interpretations within the EU legal order. It follows that the three different bodies: the Commission, the Advocate General and the CJEU, may manifest different positions, creating contradictory reliance expectations for third parties.

The most profound discussion on the role of Achmea happened in another oft-discussed case, Vattenfall $v$ Germany (II), which remains pending at the moment of writing. The Tribunal responded to the Achmea objection in a separate 74-page long decision, discussing a long range of issues from the history of the ECT's adoption to questions concerning the enforceability of arbitral awards. ${ }^{40}$ Firstly, the Tribunal agreed with the Respondent that the rendering of the Achmea judgment amounted to a timely-lodged jurisdictional objection under ICSID Arbitration Rule $41 .^{41}$ The discussion that followed concerned the compatibility of the ECT with the EU legal order. The Tribunal took international law as a common denominator, interpreting EU law as part of

\footnotetext{
$35 \quad$ Rules of Procedure for Arbitration Proceedings (Arbitration Rules) 2006 Rule 38(2).

Masdar v Spain (n 34) para 675.

Ibid., para 679.

Opinion of Advocate General Wathelet, Delivered on 19 September 2017 in Case C-284/16 Slowakische Republikv Achmea BV' ECLI:EU:C:2017:699, para 43; Masdar v Spain (Award) (n 34) para 681.

Masdar v Spain (Award) (n 34) para 682.

Vattenfall v Germany, ICSID Case No ARB/12/12, Decision on Achmea Issue, 31 August 2018.

Ibid., 98-107.
} 
international law. ${ }^{42}$ Relying on the international rules of treaty interpretation, the Tribunal found no contradictions between the ECT and the EU legal order. Accordingly, the Tribunal rejected the expansive reading of Achmea as precluding investor-state arbitration under the ECT. ${ }^{43}$

Later, in Foresight v Spain, an Stockholm Chamber of Commerce (SCC) case under the ECT, the Tribunal first clarified that pursuant to the textual interpretation of the ECT, it had jurisdiction. ${ }^{44}$ It further affirmed that only the provisions of the ECT determined the question of jurisdiction, while EU law was "not relevant to the question of the Tribunal's jurisdiction." 45 The Tribunal responded to the Achmea judgment by expressly agreeing with the Masdar v Spain award, previously discussed. ${ }^{46}$ It added that there are no known intra-EU cases where the ECT objection has worked in favour of the Respondent states. ${ }^{47}$

In RREEF $v$ Spain, an ICSID case pursuant to the ECT, the Tribunal stressed that Achmea and the case before it concerned different legal instruments. ${ }^{48}$ More importantly, it also added a few thoughts on the relationship between EU law and the ECT. The Tribunal reminded that the EU itself was a party to the ECT, which binds both the EU and non-EU states. According to the Tribunal, it would be "highly improper" for the EU to impose the incompatibility of the ECT with EU law on non-EU states. ${ }^{49}$ One may suggest that the Tribunal sought to neutralize any potential or future findings of the Court of Justice that the ECT is incompatible with EU law.

Lastly, in Greentech v Italy, the Tribunal made a strong reminder that the ECT required tribunals to decide disputes in accordance with the ECT itself and the applicable rules and principles of international law, but not EU law:

In the context of the arbitral jurisdiction created by the ECT, reference to "international law" cannot be stretched to include EU law, absent doing violence to the text which would be impermissible under the Vienna Convention on the Law of Treaties (...). ${ }^{50}$ (emphasis added)

Ibid., 150.

Ibid., 161-165.

Foresight Luxembourg Solar 1 Sàrl, et al v Kingdom of Spain, SCC Case No 2015/150, Final Award, 14 November 2018, para 212.

Ibid., 218-219.

Ibid., 220.

Ibid., 221.

RREEF Infrastructure (GP) Limited and RREEF Pan-European Infrastructure Two Lux Sà r.l v Kingdom of Spain, ICSID Case No ARB/13/30, Decision on Responsibility and on the Principles of Quantum, 30 November 2018, para 211.

$49 \quad$ Ibid.

$50 \quad$ Greentech Energy Systems A/S, NovEnergia II Energy \& Environment (SCA) SICAR, and NovEnergia II Italian Portfolio SA v The Italian Republic, Final Award, 23 December 2018, para 397. 
In conclusion, despite the broad wording of Achmea that would allow for its application to the ECT, the arbitral tribunals all came to the same conclusions: Achmea does not preclude intra-EU ECT arbitrations. Whilst one could criticize these tribunals for being too formalistic and taking too much of a textual approach, their approach is not in itself incorrect, and it is commendable that most of them engaged with EU law in quite some length. Furthermore, investment tribunals are known to rely heavily in their argumentation on the decisions of other investment tribunals. ${ }^{51}$ This is evident in the afore-mentioned reliance by the Foresight $v$ Spain Tribunal on the Masdar v Spain reasoning. Thus, once a tribunal makes an argument that Achmea does not preclude disputes under the ECT, it seems to have a 'snowball effect' and subsequent tribunals will rely on these arguments to substantiate and legitimize their own arguments.

\subsubsection{Achmea Is Not Relevant for Ongoing ICSID Cases}

Another set of arguments is used in ICSID arbitrations and concerns the relationship - both factual and legal - between Achmea and the ICSID Convention.

The Tribunal in Marfin v Cyprus - an intra-EU BIT case - reminded the parties that its jurisdiction stemmed from both the BIT and the ICSID Convention. ${ }^{52}$ The principle of the irrevocability of consent, as provided in Article 25(1) ICSID Convention, precluded revoking consent once perfected. According to the Tribunal, the Claimants managed to perfect the consent - while it was still valid - by instituting the proceedings. Thus, the Respondent lost the right to revoke it, "especially by implication," and could only withdraw it in accordance with the provisions provided in the BIT. ${ }^{53}$

In UP and $C D v$ Hungary, an ICSID case filed under the France-Hungary BIT, the Tribunal emphasized the delocalized and autonomous nature of the ICSID legal regime, which governed the claim. Conversely, the original Achmea arbitration was subject to the New York Convention regime, which allows domestic courts broader control over the arbitral proceedings and the subsequent review of the arbitral award. The Tribunal in $U P$ and $C D v$ Hungary reminded the parties that Hungary had made no attempt to withdraw its consent under the ICSID Convention. It further

\footnotetext{
$51 \quad$ OK Fauchald, 'The Legal Reasoning of ICSID Tribunals - An Empirical Analysis' (2008) 19 EJIL 2.

52 Marfin Investment Group v The Republic of Cyprus, ICSID Case No ARB/13/27, Award, 26 July 2018, para 592.

$53 \quad$ Ibid., para 593.
} 
refused to admit that EU law and Achmea can lead to such withdrawal with retroactive effect. ${ }^{54}$ Lastly, the Tribunal noted that neither state-party to the BIT tried to re-negotiate or terminate entirely the survival clause. As a result, the clause kept protecting investors even if Achmea led to the termination or inapplicability of the BIT, as suggested by the Respondent. ${ }^{55}$

One may interpret these arbitral decisions as emphasizing the importance of consent for establishing jurisdiction under the ICSID Convention. Consent has a defined timeframe and requires perfection from the investor. In both cases, the investors instituted proceedings before the Achmea judgment. The principle of the irrevocability of consent under the ICSID Convention insulates the once established jurisdiction of the Centre from any attempts of the state to terminate or invalidate the international investment agreement (IIA). ${ }^{56}$ Therefore, it is hard to argue that Achmea has any effect on ongoing proceedings under the ICSID Convention, due to both the independence of such proceedings from court review and the principle of the irrevocability of consent. At the same time, one may equally suggest that Achmea might have a preclusive effect on future ICSID claims launched after the Achmea judgment - to the extent that in intra-EU investment agreements it invalidates the open offer of the states to arbitrate.

Nevertheless, one ICSID decision stands out, as it speaks of the principle of irrevocability as being generally applicable to investment proceedings. The Tribunal in RREEF $v$ Spain did not base its reasoning on any express reference to the ICSID Convention. Instead, it suggested that once the parties have given their consent, "[n]o post-hoc decision of the Court of Justice can somehow undo that consent once given." 57 One may try to read an implied reference to the ICSID Convention, as the case at hand was an ICSID case. What seems to be equally possible, is that the wording may signal the Tribunal's desire to apply the principle of irrevocability of consent as a general principle of investment law. ${ }^{58}$ If so interpreted, the argument does not accord the Court of Justice's judgment much weight and authority.

54 UP (formerly Le Chèque Déjeuner) and CD Holding Internationale v Hungary, ICSID Case No ARB/13/35, Award, 9 October 2018, para 264.

Ibid., para 265.

Under Article 25(1) ICSID Convention, "When the parties have given their consent, no party may withdraw its consent unilaterally." See Christoph H Schreuer and others, The ICSID Convention: A Commentary: A Commentary on the Convention on the Settlement of Investment Disputes between States and Nationals of Other States (Cambridge University Press 2009) 259.

$57 \quad$ RREEF $v$ Spain (Merits) (n 48) para 213.

58 The fact that the chair is one of the most renowned public international scholars and a frequent counsel in the International Court of Justice only reinforces the presumption. 


\subsubsection{Other Arguments Used Against Achmea}

In addition to Achmea's non-application to the ECT and the irrevocability of consent argument, investment tribunals have come up with some further arguments for why the Achmea judgment does not affect their jurisdiction.

The Respondent in Marfin v Cyprus pleaded the potential unenforceability of the award due to it contradicting EU law. However, the Tribunal decided that issues of enforceability do not relate to the question of jurisdiction, which is governed wholly by the BIT and international law. The Tribunal refused to determine enforceability as its duty. Instead, it addressed it as a duty of domestic courts applying particular leges executionis. ${ }^{59}$

In another procedural twist, one tribunal referred en passant to the difference in wording in the French and English language versions of the Achmea judgment. In Greentech v Italy, the Tribunal noted that while the English version of Achmea addressed Articles 267 and 344 TFEU as "precluding provisions", ${ }^{60}$ the French version referred to them as "s 'opposent," which the Tribunal interpreted as carrying "a notion of tension or incompatibility (as between the TFEU and BIT arbitration) rather than supervening illegality." ${ }^{61}$ After concluding that Achmea is not preclusive to jurisdiction as a matter of principle, ${ }^{62}$ the Tribunal briefly agreed on the compatibility of the ECT with intra-EU ISDS.

\subsubsection{Tribunals that Refuse to Admit Achmea as a Jurisdictional Objection}

In some cases, investment tribunals relied on procedural reasons to not address Achmea, despite the effects it could potentially have on their jurisdiction and the outcome of the proceedings. Two such arguments are handled in this section: (a) the Respondent waives the jurisdictional objections based on EU law, which the Tribunal interprets as including Achmea, and (b) the Achmea objection was submitted too late.

Antaris $v$ Czech Republic is a peculiar case, as it was not the Tribunal that refused to consider the Achmea objection, but the Respondent in its counter-memorial expressly waived any

$59 \quad$ Marfin v Cyprus (Award) (n 52) para 596.

60 Greentech v Italy (Final award) (n 50) para 393 referring to CJEU Slovak Republic $v$ Achmea BV, ECLI:EU:C:2018:15862, para 62.

Greentech v Italy (Final award) (n 50) para 394.

Ibid., para 395. 
jurisdictional objections based on EU law. The waiver did not mention Achmea, but referred to 'the jurisdictional objection articulated by the Commission before [the] Tribunal. ${ }^{63}$ Based on the Commission's line of reasoning in other cases, one may suggest that the objection covered all issues of incompatibility with EU law, including the particular grounds mentioned later in Achmea.

The timeline of the proceedings can also be of crucial importance when deciding on the admission of new arguments or evidence. It is fair to expect that the proceedings should follow an established timeline as any additional interventions might compromise the integrity of the proceedings. In the ECT case of Antin v Spain, the proceedings ended a couple of weeks before the Court of Justice delivered Achmea. ${ }^{64}$ The next day, after the judgment became public, the Respondent applied for the re-opening of the proceedings. ${ }^{65}$ However, the Tribunal decided to reject the request. ${ }^{66}$ Notably, two years earlier, the Commission requested the Tribunal to allow it to participate in the proceedings. The Tribunal conditioned the Commission's participation on the acceptance of an undertaking on costs. ${ }^{67}$ Being unable to commit to such an undertaking, the Commission revoked its application for participation. ${ }^{68}$

Conversely, in Gavrilovic v Croatia, the Tribunal refused to take Achmea into account due to the Respondent's late filing of the objections, even though the proceedings were still open. ${ }^{69} \mathrm{In}$ 2012, the investor filed its claims under the Austria-Croatia BIT in accordance with the ICSID Arbitration Rules. Four years later, the parties had two series of hearings and after another two years, the Tribunal was close to rendering an award. In March 2018, the Tribunal had notified the parties that the award would come out in a few months. However, when the Respondent decided to submit a 'preliminary jurisdictional objection' based on Achmea, under ICSID Arbitration Rule 41, the Tribunal dismissed it, arguing that it was filed in a non-timely fashion. ${ }^{70}$ The justification requires a short review.

\footnotetext{
63 Antaris Solar GmbH and Dr Michael Göde v Czech Republic, PCA Case No 2014-01, Award, 2 May 2018; para 73; see also Greentech v Italy (Final award) (n 50) para 400.

64 Antin Infrastructure Services Luxembourg Sà.r.l and Antin Energia Termosolar BV v Kingdom of Spain, ICSID Case No ARB/13/31, Award, 15 June 2018, para 55.

Ibid., para 56.

Ibid., para 58.

Ibid., para 64.

Ibid., para 66.

Georg Gavrilovic and Gavrilovic d.o.o v Republic of Croatia, ICSID Case No ARB/12/39, Decision on the Respondent's Request of 4 April 2018, 30 April 2018.

Ibid., para 39.
} 
As a first ground, the Tribunal stated that the jurisdiction of an investment tribunal is not a matter of competence of the EU judicial system. Secondly, all issues raised in Achmea (except for the decision itself) belonged to public knowledge, available to the parties for years. ${ }^{71}$ The principal decision itself "is legal rather than factual in nature: it clarifies the law in the EU". ${ }^{72}$ Accordingly, the Tribunal refused to recognize it as a new fact worth addressing in the preliminary objections. Thirdly, the Respondent has never raised the incompatibility argument earlier and did not ask for the suspension of proceedings pending the Achmea decision. ${ }^{73}$ Fourthly, the Tribunal referred to a specific article of the BIT, releasing the parties from any obligations inconsistent with the EU legal order. ${ }^{74}$ Despite its authentic character and potential effect, the Respondent had not made use of that article in the course of the proceedings. ${ }^{75}$ Fifthly, the Tribunal referred to the late stage of the proceedings and the expectation of the award within just a few months. ${ }^{76}$ The two last reasons addressed a discretionary power of the Tribunal under ICSID Arbitration Rule 41(2) to consider late jurisdictional objections, which the Tribunal decided to decline. ${ }^{77}$

In less than three months, the Tribunal rendered a 376-page award, which together with the annexes totalled 757 pages. $^{78}$ In the Award, the Tribunal recognized a claim for expropriation. However, the Tribunal declined to award any significant sums of the damages claimed, recognizing less than $2 \%$ of the quantum. ${ }^{79}$

The case indicates a thin line between the questions of applicable law and the flexibility of the procedural setting, including the principle of the integrity of the proceedings and their adversary character. The failure to exercise the rights at the earliest convenience or at least to make necessary reservations may lead to adverse consequences for a party, no matter of the strength of its legal position.

Ibid., para 41.

Ibid., para 42.

Ibid., para 43.

Agreement between the Republic of Austria and the Republic of Croatia for the Promotion and Protection of Investments 1997, Art 11(2): "The Contracting Parties are not bound by the present Agreement insofar as it is incompatible with the legal acquis of the European Union (EU) in force at any given time."

Gavrilovic v Croatia (Decision on Achmea) (n 69) para 44.

Ibid., para 45.

Ibid., para 46-47.

Georg Gavrilovic and Gavrilovic d.o.o v Republic of Croatia, ICSID Case No ARB/12/39, Award, 26 July 2018.

Ibid., para 1318. 


\subsubsection{Interim Conclusions}

To conclude, there is a representative sample of cases where tribunals have assessed the relevance and legal effects of Achmea. Whilst Achmea is used by the Respondent or the Commission to target the tribunals' jurisdiction, tribunals may accept it as a jurisdictional objection or reject it under various procedural grounds. One may also trace the formation of a jurisprudence constante concerning the relationship between the ECT and Achmea, the tribunals ignoring the applicability of the latter. Another example is the alleged non-applicability of Achmea in ICSID cases due to the principle of the irrevocability of consent under the ICSID Convention. Rather unexpectedly, even in non-ICSID cases filed under intra-EU BITs, tribunals found at least one ground to dismiss Achmea, due to late submission. As a result, in none of the observed cases did objections based on the Achmea judgment lead to the termination of intra-EU investment treaty arbitration cases.

\section{Rendering an Award When it is Unenforceable in/by one of the Disputing Parties}

In order to provide some analytical clarity, we need to differentiate between several concepts and perspectives. One is the difference between the existence of an international adjudicatory mechanism and the enforceability of its awards. The other is the different perspectives one can take, depending on whether it is an EU or an international law perspective.

From the perspective of EU law, after the Achmea judgment, the very existence of arbitral tribunals under intra-EU BITs is precluded by EU law. In other words, from the perspective of EU law, awards rendered by intra-EU arbitral tribunals are unenforceable in the EU because the very existence of the tribunals that rendered them is precluded by EU law. Conversely, from the perspective of international law, until the contracting parties to the intra-EU BITs do not amend or terminate them (and the ECT), investors will be able to bring arbitral claims and tribunals will be validly constituted under international law. Furthermore, if the contracting parties do not terminate the sunset clauses, arbitral tribunals can be validly constituted under these agreements, even if investors bring claims following their termination. In other words, until the EU Member States do not act on the international level, these arbitral tribunals are validly constituted and deliver awards which can be enforced under the New York Convention or the ICSID Convention.

Given this conundrum, the likelihood that the number of intra-EU arbitral cases will rise in the upcoming years is high, as signalled by the high number of pending cases in Annex 1. 
Furthermore, as the previously analysed cases clearly show, arbitral tribunals always find a way to uphold their jurisdiction when the Respondent or the Commission challenge their jurisdiction pursuant to EU law arguments.

This being said, the first part of this section discusses how the rendering of potentially unenforceable decisions by international tribunals is not specific to intra-EU investment disputes. We then discuss why intra-EU investment tribunals might uphold their jurisdiction and render an award when they know that the Respondent will not/cannot enforce it.

\subsection{It is Not Specific to Intra-EU Investment Disputes}

The rendering of a decision by an international tribunal, when it knows in the jurisdictional or the merits phase that one of the disputing parties will not enforce it or comply with it, is not restricted to investment law.

The South China Sea arbitration ${ }^{80}$ is a telling example. In this case, the Philippines unilaterally initiated compulsory arbitration pursuant to Article 287 and Annex VII of the UN Convention on the Law of the Sea (UNCLOS) concerning the role of China's 'historic rights' and maritime entitlements in the South China Sea. China unequivocally rejected the arbitration and protested by not participating. ${ }^{81}$ Despite China's protests, the UNCLOS Tribunal ended up delivering a first award on jurisdiction and admissibility, ${ }^{82}$ followed by a final award on the merits. ${ }^{83}$ The Tribunal had done so knowing that China will most probably not comply with the award. Following the rendering of the final award, China maintained its position that the arbitration was a "political farce and the award was illegal, null, and void". ${ }^{84}$

The Arctic Sunrise dispute, concerning the seizing of a Greenpeace ship by the Russian authorities, is another example of an international tribunal having to render a decision knowing that the Respondent state will most likely not comply with it. In the case brought by the Netherlands against Russia before the International Tribunal for the Law of the Sea (provisional measures) and

PCA, The South China Sea Arbitration (The Republic of Philippines v The People's Republic of China), Case No 2013-19 <https://pca-cpa.org/en/cases/7/> accessed 1 June 2019.

81 For a fairly one-sided, Chinese perspective on the arbitration see Chinese Society of International Law, 'The South China Sea Arbitration Awards: A Critical Study' [2018] 17 Chinese Journal of International Law 207. See also, Y Mincai, 'China's Responses to the Compulsory Arbitration on the South China Sea Dispute: Legal Effects and Policy Options' [2014] 45 Ocean Development \& International Law 1.

82 The South China Sea Arbitration (n 80) Award on Jurisdiction and Admissibility, 29 October 2015.

83 The South China Sea Arbitration (n 80) Award, 12 July 2016.

84 H Duy Phan, L Ngoc Nguyen, 'The South China Sea Arbitration: Bindingness, Finality, and Compliance with UNCLOS Dispute Settlement Decisions’ [2017] 38 Asian Journal of International Law 36, 37. 
an Annex VII UNCLOS Tribunal, Russia informed both the Netherlands and ITLOS that "it does not accept" the Annex VII Arbitration and it did "not intend to participate" in the ITLOS proceedings for the prescription of provisional measures. ${ }^{85}$ Russia based its non-participation on a statement made upon the ratification of UNCLOS, according to which it does not accept procedures entailing binding decisions with respect to disputes "concerning law-enforcement activities in regard to the exercise of sovereign rights or jurisdiction". ${ }^{86}$ Despite these objections, ITLOS ordered that the ship and the detained persons should be immediately released. ${ }^{87}$ The Annex VII Tribunal ruled that it had jurisdiction and that Russia's declaration upon the ratification of UNCLOS did not exclude the dispute. ${ }^{88}$ Furthermore, Russia had to compensate the Netherlands, as the flagship country, for breaching UNCLOS. ${ }^{89}$

Another set of notable cases are the investor-state arbitrations against Russia arising after the Crimean Annexation. As of 2015, investors have been filing claims against Russia under the Russia-Ukraine BIT for the alleged interference and expropriation of their investments in Crimea. The Russian response to all the claims has been consistent over the years. According to the first available press-releases, Russia informed the PCA that it does not recognize the tribunals' jurisdiction under the BIT and chooses not to appoint any representatives. ${ }^{90}$ Russia has not shown up in the course of the proceedings, did not attend the hearings or otherwise participate. Nevertheless, tribunals tend to accept jurisdiction over the investors' claims. Some of them have resulted in awards on the merits against Russia. ${ }^{91}$ In all these cases, the tribunals faced a denial of

85

Note Verbale of the Embassy of the Russian Federation in Berlin, 22 October 2013, $<$ https://www.itlos.org/fileadmin/itlos/documents/cases/case_no.22/Note_verbale_Russian_Federation_eng.p df $>$ accessed 1 June 2019.

$86 \quad$ Ibid., p 2.

87 ITLOS, The 'Arctic Sunrise Case' (Kingdom of the Netherlands v Russian Federation), Provisional Measures, Order of 22 November 2013, p 252.

PCA, The Artic Sunrise Arbitration (Netherlands v Russia), Case No 2014-02, Award on Jurisdiction, para 79. PCA, The Artic Sunrise Arbitration (Netherlands v Russia), Case No 2014-02, Award on Compensation, para 128.

Aeroport Belbek LLC and Mr Igor Valerievich Kolomoisky v The Russian Federation, PCA Case No 2015-07, Press Release, 6 January 2016; JSC CB PrivatBank and Finance Company Finilon LLC v The Russian Federation, PCA Case No 2015-21, Press release, 30 March 2016; LLC Lugzor et al v The Russian Federation, PCA Case No 2015-29, Press Release, 13 December 2017; PJSC Ukrnafta v The Russian Federation, PCA Case No 2015-34, Press Release, 2 May 2016; Stabil LLC et al v The Russian Federation, PCA Case No 201535, Press Release, 2 May 2016; Everest Estate LLC et al v The Russian Federation, PCA Case No 2015-36, Press Release, 9 August 2016; NJSC Naftogaz of Ukraine (Ukraine) et al v The Russian Federation, PCA Case No 2017-16.

Everest Estate LLC et al v The Russian Federation, PCA Case 2015-36, Press Release, 9 May 2018; Aeroport Belbek LLC and Mr Igor Valerievich Kolomoisky v The Russian Federation, PCA Case No 2015-07, Press 
jurisdiction by the Respondent and had to decide on the matter without any expectation of voluntary compliance.

In the case of the intra-EU investment arbitrations, the non-enforcement of the awards is also not hypothetical, but a reality and an obligation under EU law. So far, we have seen two types of incompatibility with EU law that led to the non-enforcement of the arbitral award. Firstly, in the case of the Micula I award ${ }^{92}$ - rendered prior to the Achmea judgment - the arbitral tribunal itself was not deemed to be incompatible with EU law (at that point in time). What was deemed to be incompatible - by the Commission - was the compliance with the award by Romania, i.e. the payment of damages by Romania to an EU investor, which contravened EU state aid rules. ${ }^{93}$ The Romanian Constitutional Court also gave precedence to the primacy of EU law over Romania's international obligations under ICSID. ${ }^{94}$ The second type of incompatibility - following the Achmea judgment - concerns the incompatibility of the tribunal itself with EU law. In such a case, the mere existence of the arbitral tribunal is precluded by EU law. Following the Court of Justice's judgment in Achmea, the Federal Court of Germany - the court that made the preliminary reference to the Court of Justice - ended up setting aside the original Achmea award. ${ }^{95}$

In the next section the paper looks at why international tribunals render awards which are very likely not to be enforced/complied with by the Respondent state.

\subsection{Why Do International Tribunals Uphold their Jurisdiction when they Render Potentially Unenforceable Awards?}

Whilst different in many ways - the subject area, the applicable legal rules, the procedure, the tribunals - the common element in the South China Sea case, the Arctic Sunrise case, the investment arbitrations arising out of the Crimean dispute, and the post-Achmea intra-EU arbitrations is that

Release, 15 February 2019; JSC CB PrivatBank and Finance Company Finilon LLC v The Russian Federation, PCA Case No 2015-21, Press Release, 15 February 2019.

92 Ioan Micula et.al. v Romania, ICSID Case no ARB/05/20, Final Award, 11 December 2013.

93 EC Decision 2015/1470 of 30 March 2015 on State aid SA.38517 (2014/C) (ex 2014/NN) implemented by Romania - arbitral award Micula v. Romania of 11 December 2013, OJ L 232, 43.

94 Constitutional Court of Romania (Curtea Constituțională a României), Decision No 887 of 15 December 2015 ('Micula and European Food').

Federal Court of Germany (Bundesgerichtshof), Case I ZB 2/15, Decision of 24 January 2019. See S Schwalb and S Arzner, 'The German Federal Court of Justice rules in Achmea - entry into the EU renders Slovakia's offer for Intra-EU arbitration inapplicable' [2019] <https://www.lexology.com/library/detail.aspx?g=a7e2bce4-8334-4fcb-a397-61709c3b095d >, accessed 1 June 2019. 
the tribunals in the jurisdictional phase already knew that the Respondent (most likely) will not enforce the awards or comply with them. The tactics used by the Respondents differed. China did not participate in the arbitration and initiated a campaign to undermine the credibility of the UNCLOS Tribunal, Russia sent a note verbale to ITLOS and the Netherlands concerning its non-participation, whilst the EU Member States participated in the arbitrations brought against them and raised legal arguments against the tribunals' jurisdiction. The outcomes were the same: the tribunals upheld their jurisdiction and decided on the merits.

The question is why tribunals choose to uphold their jurisdiction when it is almost certain that the respondents will not comply with their decisions or enforce the awards. This question is even more important if one accepts the traditional view that compliance is central to the effectiveness and legitimacy of international law and adjudication. ${ }^{96}$ However, as Davenport argues - in the context of the South China Sea Arbitration and using the ICJ's Nicaragua judgment against the USA as an example - the decision of an international tribunal has value, even if it is not complied with, such as enhancing the legitimacy of the system, interpreting the law, shaping future negotiations between the disputing parties, and impacting other state and non-state actors. ${ }^{97}$ Therefore, in the following, we argue that several reasons exist - depending on whether one takes a more conservative, dogmatic view or a law in context approach - as to why intra-EU investment tribunals still go forward with their decisions.

Firstly, one can take a more dogmatic view and argue that the intra-EU tribunals did nothing more than read and interpret the legal rules granting them jurisdiction, which allowed them to conclude that they had jurisdiction. Thus, such tribunals derive their jurisdiction from international agreements which are still valid under international law, and the EU treaties have not replaced or superseded the intra-EU BITs when newer states joined the EU. However, when every, independently constituted intra-EU tribunal comes to the same conclusion - affirming their jurisdiction - even when the cases are different and the legal arguments being raised differ, then one wonders if the outcome is really based only on what the law allows them to conclude. As

96 Y Shany, Assessing the Effectiveness of International Courts (OUP 2014) 117. Shany takes the view that judgment-compliance "is not a reliable indicator of judicial effectiveness" p 118. For a discussion of why states comply with international law, see A Guzman, How International Law Works: A Rational Choice Theory' (OUP 2008) who coins the expression the "Three Rs of Compliance": reciprocity, retaliation ad reputation.

97 T Davenport, 'Why the South China Sea Arbitration Case Matters (Even if China Ignores It)' [2016] The Diplomat, 8 July 2016 <https://thediplomat.com/2016/07/why-the-south-china-sea-arbitration-case-matterseven-if-china-ignores-it/> accessed 1 June 2019. 
Koutrakos noted in the intra-EU BIT context prior to Achmea, intra-EU investment tribunals take an unduly formalistic view on the matter of jurisdiction and only focus on the narrow issue of compliance with international law, disregarding the complexities faced by "national courts [...] called upon to enforce the award whilst they [...] struggle to identify their obligations under parallel and interacting sets of rules'. ${ }^{98}$ Whilst this might be the case for intra-EU BITs, it is hard to argue that the South China Sea or Arctic Sunrise Tribunals took an unduly formalistic attitude towards their jurisdiction under UNCLOS, when the respondents did not even participate in the disputes to raise legal arguments against the jurisdiction of those tribunals..

Secondly, one could argue that the tribunals might interpret their jurisdiction more broadly or narrowly depending on the effectiveness of the enforcement/compliance mechanism of the legal regime they operate in. Thus, international tribunals will interpret their jurisdiction narrowly if they know that compliance with their decision or its enforcement is only dependent on the Respondent state. Conversely, tribunals will interpret their jurisdiction broadly if compliance or enforcement is not solely dependent on the Respondent state. For example, investment law has quite an effective enforcement mechanism, via the New York and ICSID Conventions. Thus, in an ICSID arbitration, the investor can seek to enforce its award in any member of the ICSID Convention. In other words, if the respondent State fails to enforce the award, the investors can seek enforcement in another ICSID member, just like the Micula brothers sought enforcement in US courts. ${ }^{99}$

It follows that intra-EU tribunals might be willing to interpret their jurisdiction expansively and disregard Achmea, because they know that their awards are enforceable in non-EU countries, even if the EU Member States argue that they cannot enforce the awards due to EU legal impediments. Nonetheless, we see the opposite in the South China Sea dispute. Even if the Tribunal knew that compliance with the award by an objecting member of the UN Security Council will likely be impossible and there was no other effective means of enforcement, it still upheld its jurisdiction and decided the case. ${ }^{100}$ Furthermore, as previously discussed, the investment tribunal in Marfin v Cyprus decided that issues of enforceability do not relate to the question of jurisdiction, governed wholly by the BIT and international law, and it refused to determine enforceability as its

98 P Koutrakos, 'The Relevance of EU Law for Arbitral Tribunals: (Not) Managing the Lingering Tensions' [2016] 17 JWIT 873, 880.

99 For example US District Court for the District of Columbia, Viorel Micula v The Government of Romania, Civil No 1:14-cv-00600, Decision on the Claimant's Motion to confirm the ICSID Award.

100 As Phan and Nguyen point out, compliance with UNCLOS arbitrations is quite high, with only the Arctic Sunrise and South China Sea disputes as exceptions. See Phan and Nguyen (n 84) 47. 
duty. ${ }^{101}$ Thus, at least for some international tribunals, the effectiveness of the compliance or enforcement mechanism does not seem to influence how broadly they interpret their jurisdiction.

Thirdly, as Shany notes, it might also be that international courts "hungry for cases or eager to advance a certain normative agenda may read their jurisdictional powers in an expansive manner". ${ }^{102}$ To what extent this might be the case for intra-EU BITs is hard to tell. On the one hand, one can argue that investment tribunals cannot be hungry for more cases, since - unlike standing international courts - they are only set up to adjudicate a specific case, after which they are dissolved. On the other hand, it could be argued that arbitrators - some of whom are repeatedly appointed $^{103}$ - want to send a signal to investors that despite the Achmea decision, investor-state arbitration is a viable dispute resolution mechanism and the system is apt to hear potential cases. This idea does not seem that farfetched. As Fauchald's empirical analysis from 2008 shows, ICSID tribunals have a tendency of developing a homogenous methodology - despite their ad hoc nature and the heterogeneous legal sources based on which they have to solve legal disputes - using case law from other investment tribunals as their main interpretative argument. ${ }^{104}$ We see the same tendency in the intra-EU BIT cases as well (both pre and post-Achmea) in which tribunals often rely on arguments used by previous tribunals to dismiss the objections to their jurisdiction based on EU law and the Achmea judgment. ${ }^{105}$

Fourthly, some goals of international tribunals seem to be common to all judicial institutions, goals such as a normative agenda, "dispute resolution, problem solving, regime support, and legitimation."106 One can thus argue that the intra-EU tribunals are willing to uphold their jurisdiction even after Achmea because their primary role is to solve the dispute between an investor and the host State, as well as to interpret and clarify the law. ${ }^{107}$ Whether or not compliance and enforcement can be achieved, does not affect the main task of investment tribunals: the settlement of investor-State disputes (see the Marfin v Cyprus Tribunal) and the interpretation of the law. Furthermore, the Court of Justice's Achmea ruling in essence questions the very existence of such tribunals; a regional court, deriving its jurisdiction from another set of international treaties, is

\footnotetext{
$101 \quad$ Marfin v Cyprus (Award) (n 52) para 596.

$102 \quad$ Shany (n 96) 79.

103 See M Langford, D Behn and R Lie, 'The Revolving Door in International Investment Arbitration' [2017] 20(2) Journal of International Economic Law 301.

See Fauchald (n 51).

See n 46; the Foresight $v$ Spain Tribunal referred to the arguments of the Masdar $v$ Spain Tribunal.

Shany (n 96) 123.

See also Davenport (n 97).
} 
telling another international tribunal (even if just $a d$ hoc) that their very existence under a different set of international treaties is precluded by the former set of treaties. Thus, one should not be surprised that in an effort to legitimize the investment law system based on which they operate, intra-EU tribunals will push back against Achmea. This push-back is most evident in RREEF $v$ Spain in which the Tribunal went as far as to criticize the part of the Achmea judgment in which the Court of Justice differentiates between commercial and investment treaty arbitration. ${ }^{108}$ Henceforth, even if on the surface most investment tribunals take account of the Court of Justice's judgment and engage with EU law, their ultimate decision is not affected by it.

Fifthly, ad hoc tribunals do not have security of tenure as standing tribunals do and the remuneration of their members will depend on each individual case. More so, depending on the institutional rules under which the arbitration is conducted, arbitrators might receive their remuneration after different stages of the proceedings. In other words, the longer the proceedings the more remuneration they will get. Thus, one could argue that it makes more sense to uphold jurisdiction and continue a case if this affects the remuneration of the arbitrators.

In conclusion, intra-EU investment tribunals can have various reasons to uphold their jurisdiction and decide on the merits, even if they know that following the Achmea judgment, the Respondent states will not be able to enforce their awards. The most compelling reason seems to be the one evoked by the Marfin v Cyprus Tribunal. Enforceability is a separate issue from jurisdiction. Thus, in the jurisdictional phase a tribunal should decide based on the law in front of it, and not whether the decision will be enforced or complied with.

\section{$4 \quad$ The Way Forward?}

From the perspective of the effective administration of justice the present situation is clearly untenable. Two different judicial fora have opposite views on the same matter: according to the Court of Justice the very existence of intra-EU investment tribunals is precluded by EU law, while the arbitral tribunals disagree with the Court of Justice and uphold their jurisdiction on international law grounds. As Witte notes: 
... neither system with its respective adjudicative body can forcefully subordinate the other to its will. Although either system with its respective adjudicative body maintains its claim to supremacy, the reality of their relationship is one of heterarchy. ${ }^{109}$

The effects of the tension between EU and investment law, however, do not stop at the disagreement of two adjudicative bodies or at the level of academic debates. For investors, host States, and national courts - both EU and non-EU - the status quo creates uncertainties. Investors that won the arbitration and are awarded compensation, cannot enforce it in $28 \mathrm{EU}$ Member States, so they have to spend extra time and resources to enforce the awards in non-EU countries, without the guarantee of success. ${ }^{110}$ National courts are also put in a delicate position. EU national courts must choose between two competing legal obligations: those under EU law and those under their investment agreements, as well as the ICSID and New York Conventions. Under EU law, they will have to grant primacy to their EU law obligations. Non-EU courts, such as those of the United States, are then asked to tackle the enforcement of such awards. This in turn exposes them to the murky and muddied waters of the relationship of these agreements with the internal legal order of another international actor. EU Member States are also in a position of not knowing whether or not to continue challenging the jurisdiction of intra-EU investment tribunals or simply move forward with the arbitration. ${ }^{111}$ Later on, if they choose to enforce the arbitral awards, they will contravene EU law and risk an infringement case, as the example of Romania shows in the Micula I case.

In the following we argue that in the interest of the effective administration of justice ${ }^{112}$ investment tribunals could give more weight to the Achmea judgment and decline their jurisdiction as a sign of judicial comity. Otherwise, they could still uphold their jurisdiction, but decline the case as inadmissible for the interest of upholding the effective administration of justice. We of course

I Witte, 'Interaction between International Investment Law and Constitutional Law: Promoting the Dialogue. A European Perspective on Judicial Cooperation and Deference' [2018] 21(1) Max Planck Yearbook of United National Law Online 469, 516. On legal heterarchy see D Halberstam, 'Constitutional Heterarchy: The Centrality of Conflict in the European Union and the United States', in JL Dunoff and JP Trachtman (eds), Ruling the World? Constitutionalism, International Law and Global Governance (CUP 2009). See, for example, USDC for the District of Columbia, Novenegia II v Kingdom of Spain Civil Action No. 1:18cv-1148 in which the investor is seeking to confirm an arbitral award against Spain. See US District Court for the District of Columbia, Viorel Micula $v$ The Government of Romania (n 99) in which the US court denied the investors' petition to confirm the ICSID Award.

111 See (n 63) the waiver of the jurisdiction objections by the Czech Republic.

112 For this idea see Caroline Henckels, 'Overcoming Jurisdictional Isolationism at the WTO - FTA Nexus: A Potential Approach to the WTO’ [2008] 19(3) EJIL 571. 
realise that in light of what we have seen so far, most of these proposals will remain at the theoretical level.

\subsection{Judicial Comity. Doubtful it will Work}

The interaction between EU law and investment law is not new to academic debates. Recently, Witte argued in favour of judicial dialogue following a 'heterarchical conceptualization' of the relationship between the two fields of law, which:

...should further prompt investment tribunals to abstain from isolationist constructions of international investment law because only decisions that engage in the difficult exercise of balancing conflicting interests can find constitutional acceptance. ${ }^{113}$

This proposal - made prior to the delivery of the Achmea judgment - cannot, however, adequately address the post-Achmea reality. The very existence of these tribunals is precluded by or is incompatible with - depending on which translation of the judgment one follows - EU law. Thus, no amount of balancing of conflicting interests by intra-EU tribunals will gain constitutional acceptance by the Court of Justice. Furthermore, some judicial dialogue has already occurred at the level of judicial engagement. We have seen that some intra-EU tribunals, especially the one in Vattenfall, have extensively considered EU law and Achmea, without declining their jurisdiction. Therefore, we believe that - given the current situation - dialogue might not be sufficient to solve the conundrum and instead we look at whether judicial comity could provide some guidance (albeit with the reservation that in practice tribunals probably will not consider it).

According to the Oxford Reference definition, 'judicial comity' refers to the "principle that, out of deference and respect, the courts in one state or jurisdiction will give effect to the laws and judicial decisions of another". ${ }^{114}$ As Henckels notes, "it allows a court to decline to exercise jurisdiction over matters that would be more appropriately heard by another tribunal," but it does not impose a legal obligation on tribunals. ${ }^{115}$

\footnotetext{
$113 \quad$ Witte (n 109) 519.

114 Oxford Reference <http://www.oxfordreference.com/view/10.1093/oi/authority.20110803100026381> accessed 1 June 2019; See JR Paul, 'Comity in International Law ' [1991] 32(1) Harvard Int'l LJ 2. One could also draw parallels with the common law doctrine of forum non conveniens, a conflict of laws doctrine that applies between courts in different jurisdictions in the same country or between courts of different countries. Henckels (n 112) 584. Swarabowicz pleads for the consolidation of investment cases according to private law rules, see M Swarabowicz, 'Identity of Claims in Investment Arbitration: A Plea for Unity of the Legal System' [2017] 8 Journal of International Dispute Settlement 280.
} 
This concept is not alien to international law. The MOX Plant dispute between Ireland and the United Kingdom, concerning the deposit of nuclear waste close to the Irish Sea, ended up before three international/regional tribunals: the Court of Justice of the EU, ${ }^{116}$ an UNCLOS Annex VII Tribunal, ${ }^{117}$ and a Tribunal constituted under the OSPAR Convention. ${ }^{118}$ The UNCLOS Annex VII arbitration is the posterchild of judicial comity between two different international courts. The Tribunal suspended the proceedings based on the principle of mutual respect and comity until a pending issue that affected the tribunal's jurisdiction was handled by the Court of Justice.

One could argue that in the interest of the effective administration of justice, intra-EU tribunals (both those based on the ECT and BITs) could, pursuant to the principle of mutual respect and comity, decline their jurisdiction. Henckels argues that tribunals possess the inherent power to find that they do not have jurisdiction in a case and to decline to exercise it. ${ }^{119}$ This, however, has yet to happen in intra-EU cases (and we are doubtful that it will), even in cases in which the MOX Plant arbitration was relied on by the Respondent.

In the UP and $C D v$ Hungary arbitration - commenced under the France-Hungary BIT - the tribunal had to consider whether the MOX Plant arbitration ${ }^{120}$ under UNCLOS could give it guidance. The Tribunal succinctly concluded that MOX Plant "provides no useful guidance in view of the considerable differences between that case and the present one". ${ }^{121}$ According to the Tribunal, the two cases differ because in MOX Plant the EU was a party to UNCLOS, there was a risk of future conflicting decisions, and the MOX Plant Tribunal in the end did not decide on its jurisdiction because Ireland withdrew its claim. ${ }^{122}$

The decision of the Tribunal is not without criticism. The Tribunal takes an overly formalistic reading of MOX Plant and why it was relevant to the case. It was relevant because it was an example of how one tribunal can act - suspending the proceedings- when its jurisdiction might be/is affected by another international tribunal. Thus, the essence of both cases was similar. Furthermore, since

116 CJEU C-459/03, Commission v Ireland [2006] ECLI:EU:C:2006:345.

117 PCA, UNCLOS Arbitral Tribunal, The MOX Plant Case (Ireland v. United Kingdom), PCA Case 2002-01, Order of 24 June 2003. See N Lavranos, 'The Epilogue in the MOX Plant Dispute: An End Without Findings' [2009] 18(1) European Energy and Environmental Law Review 180. PCA, OSPAR Arbitral Tribunal (MOX Plant), (Ireland v United Kingdom), PCA Case NO 2001-03, Final Award, 2 July 2003.

$119 \quad$ Henckels (112) 583.

120 PCA, UNCLOS Arbitral Tribunal, The MOX Plant Case (n 117).

$121 \quad U P$ and DC v Hungary, ICSID Case No ARB/13/35, Award, 9 October 2018, para 276.

122 Ibid., paras 277-279. 
the EU is a party to the ECT, it would follow from the Tribunal's logic that the MOX Plant case would be applicable to ECT cases.

In the original Achmea $v$ Slovakia arbitration, the Respondent and the Commission also raised the argument of judicial comity pursuant to the Mox Plant arbitration ${ }^{123}$ and advised the Tribunal to follow the MOX Plant Tribunal and suspend the proceedings. The Tribunal ended up not addressing this argument.

Prior to Achmea, Koutrakos argued that investment tribunals would either engage or not engage with EU law at all. He gave the example of the tribunal in EURAM $v$ Slovakia $^{124}$ as an illustration of the tribunal's engagement with and understanding of EU law, even if in the end the tribunal upheld its jurisdiction. Whilst this example is commendable, the empirical part of this paper clearly shows that so far in none of the pre and post-Achmea cases did the tribunals relinquish their jurisdiction pursuant to objections based on EU law. Thus, whether or not a tribunal engages with EU law makes little practical difference if they still uphold their jurisdiction. In other words, engagement with EU law that is not followed by a relinquishment of jurisdiction is not enough to provide more legal certainty and coherence.

There are some further issues to consider as well with the proposal that intra-EU tribunals should decline their jurisdiction based on judicial comity. Firstly, what is the benefit of this approach and to whom? One can of course argue, as we have previously done, that this would benefit the effective administration of justice and it would provide legal certainty. The counter argument to this, is that it will not benefit investors who expect that a certain level of protection is offered to them by IIAs. They have a right to initiate a claim, granted to them by sovereign states pursuant to an international treaty, and the Tribunal would deprive them from that right by declining its jurisdiction. On the other hand, it can also be argued that by going forward with the case, intra-EU tribunals help create more uncertainty for the investors. Probably not many investors want to spend millions of dollars on expensive, multi-year arbitrations (the average of which takes 4 years), ${ }^{125}$ just

PCA Eureko (Achmea) v Slovakia, Case No 2008-13, Award on Jurisdiction, Arbitrability and Suspension, 26 October 2010, paras 195 and 203.

Koutrakos (n 98) 881, with reference to EURAM v Slovakia, PCA Case No 2010-17, Award on Jurisdiction, 22 October 2012.

A Sinclair, 'ICSID arbitration: How Long Does it Take?' [2009] 4(5) Global Arbitration Review (115 ICSID cases took on average 3.63 years); Allen \& Overy, 'Investment Treaty Arbitration: Cost, Duration and Size of Claims all Show Steady Increase' [2017] (324 cases took on average 3.8 years) $<$ http://www.allenovery.com/publications/en-gb/Pages/Investment-Treaty-Arbitration-cost-duration-andsize-of-claims-all-show-steady-increase.aspx ISA> accessed 1 June 2019; Joongi Kim, 'Streamlining the 
to find out that the award is unenforceable. Whilst outside-EU enforcement is possible under ICSID, there is no conclusive empirical evidence of how many of the enforcement cases launched by the investors before third-country courts have proven to be successful.

Secondly, the UP and CD v Hungary Tribunal raised the question of which neutral forum would be competent to hear the dispute in the eventually that it declined jurisdiction because the Respondent failed to show that the Claimants would have standing before the domestic courts. Furthermore, the "vague principle" of mutual trust that applies between EU Member States and their courts, is inapplicable to investment tribunals. ${ }^{126}$

The question of which neutral forum would hear the dispute in case the investment tribunals were to decline their jurisdiction has both a legal and a factual component to it. If the treaty has a fork-in-the-road clause ${ }^{127}$ or a non-U turn clause, ${ }^{128}$ then the investor could technically not rely anymore on domestic courts. ${ }^{129}$ In reality, however, fork-in-the-road clauses are easy to circumvent. In order for this clause to properly operate one would need an identity of the facts, the disputing parties and the legal rules invoked. In most cases, however, the domestic dispute is brought by a different legal entity than the international one, the facts of the domestic case differ, as well as the legal rules invoked in the case. ${ }^{130}$ Thus, if intra-EU investment tribunals were to decline their jurisdiction, the investors could still bring a case before domestic courts, the latter being a fairly widespread option even when investor have the opportunity to resort to investment treaty arbitration. ${ }^{131}$

In conclusion, whilst judicial comity that results in a declination of jurisdiction in favour of EU courts (both national and EU level) might seem to be a more far-reaching solution, than judicial dialogue in the form of judicial engagement, we believe that in practice - as already shown by two cases - intra-EU tribunals will not follow this approach.

\footnotetext{
ICSID Process: New Statistical Insights and Comparative Lessons from Other Institutions' [2004] 11(1) Transnat'1 Dispute Mgmt. 2 (on average 4.1 years).

$126 U P$ and DC v Hungary, ICSID Case No ARB/13/35, Award, 9 October 2018, para 222.

127 Fork-in-the-road clauses require the investor to decide whether it chooses domestic courts or ITA, prohibiting it to have recourse to the other forum once it has made its choice.

128 'No-U-turn' clauses forbid the investor to resort to domestic courts, once it has opted for ITA.

129 UNCTAD, 'Investor-State Dispute Settlement' [2014] UNCTAD Series on Issues in International Investment Agreements III, 86-87 < https://unctad.org/en/PublicationsLibrary/diaeia2013d2_en.pdf> accessed 1 June 2019.

130 See Sz Gáspár-Szilágyi, 'Why Do or Should Foreign Investors Resort to the Courts of the Host Country Prior to Investment Treaty Arbitration?' in OK Fauchald, D Behn, MLangford (eds), The Legitimacy of Investment Arbitration. Empirical Perspectives (forthcoming, CUP 2019/2020). Ibid.
} 


\subsection{Uphold the Jurisdiction but Declare the Case Inadmissible?}

The second proposal we discuss is a bit more controversial as it relies on differentiating between jurisdiction and admissibility. Whilst the difference between the two is a debated topic and academics differ ${ }^{132}$ as to where the separation between the two lies, we take the views expounded by Shany and Reinisch to differentiate between the two concepts. According to Shany, the jurisdiction of a court - dictating who can access the court, when, which issues can be litigated, etc. - is set out in the constitutive documents of the court. Traditionally, one speaks of four facets of jurisdiction: ratione materiae, ratione temporae, ratione personae, and ratione loci. ${ }^{133}$ Admissibility, on the other hand, denotes a court's discretionary power to admit a specific case or not; the power to decline hearing the case even when it has affirmed jurisdiction. ${ }^{134}$ Thus, in the words of Reinisch "[i]n this sense, jurisdiction is a primary issue which has to be affirmed first; and admissibility may be a secondary issue that only arises once a tribunal has affirmed its jurisdiction." 135

Based on the above, one could argue that an intra-EU tribunal could fist uphold its jurisdiction, despite the objections based on Achmea, but then decide that the case is inadmissible. However, based on what ground(s) could an intra-EU tribunal do so? According to Shany, "rules on admissibility allow courts to engage in some degree of case selection according to their internal policy preferences and in response to external expectations [emphasis added]." ${ }^{136}$ Therefore, the grounds for declining admissibility would be at the discretion of the tribunals.

Some international courts dismiss a case on the basis of 'external' legal rules, which are not found in the constitutive instruments of the court. This may suggest "that an international court [can regard] the need to protect the systemic welfare of international law as a worthy goal that must be pursued". ${ }^{137}$ International courts have also upheld "their right to decline jurisdiction in

132 See V Heiskanen, ‘Comments on Andrea Marco Steingruber's Remarks on Veijo Heiskanen’s Note 'Ménage a Trois? Jurisdiction, Admissibility and Competence in Investment Treaty Arbitration' [2014] 29(3) ICSID Rev 669.

133 Shany (n 96) 67-68.

134 Shany (n 96) 84.

135 August Reinisch, 'Jurisdiction and Admissibility in International Law' [2017] 16 JWIT 21, 24.

136 Shany (n 96) 68.

137 Shany (n 96) 87. 
circumstances where the exercise of [it] would have run contrary to a legal principle". ${ }^{138}$ Could one argue that 'effective administration of justice' is such a principle or an 'external' legal rule?

In light of what we have seen, an argument could be made that the current tangled web of national, supranational and international procedures does not ensure the effective administration of justice. Thus, intra-EU tribunals - instead of declining their jurisdiction based on EU law and Achmea - could continue upholding their jurisdiction based on the IIAs. This would ensure that the way in which jurisdiction is upheld in investment law is consistent within the system. Nevertheless, once jurisdiction is upheld, they could decline to admit the case pursuant to the need to ensure the effective administration of justice. We are of course aware that this is a longshot as "international courts sometimes tend to retain cases when they face a strong institutional interest in doing so, even in the face of jurisdictional competition." 139

In conclusion, upholding their jurisdiction and then dismissing the case based on the effective administration of justice could help the intra-EU tribunals to continue past practice relating to the effects of EU law on their jurisdiction - thus safeguarding the coherence of the investment law system - and it would also ensure that they would be perceived as a more legitimate system. Nevertheless, the likelihood that in practice they will adopt this approach is very low.

\section{Conclusion}

Following the Court of Justice's recent Achmea judgment, there is already a representative sample of cases in which intra-EU investment tribunals have assessed the relevance and legal effects of Achmea. The number of pending cases is staggering and will continue to rise, ensuring that the relationship between the EU legal order and Achmea, on the one hand, and the Energy Charter Treaty and intra-EU BITs, on the other, will remain topical in the years to come.

Whilst Achmea is used by the Respondents or the Commission to object to the tribunals' jurisdiction, tribunals have so far consistently rejected these objections and have upheld their jurisdiction. The reasons vary among the tribunals, but one can already observe the formation of a

\footnotetext{
138 Shany (n 96) 86 with reference to Rights of Minorities in Upper Silesia (Minority Schools) (Germany v Poland) [1928] PCIJ Series A No 15, 23 and Case of the Monetary Gold Removed from Rome in 1943 (Italy v France, United Kingdom of Great Britain and Northern Ireland and United States of America) (Preliminary Question) [1954] ICJ Rep 19, 32.

139 Shany (n 96) 94.
} 
jurisprudence constante concerning the relationship between the ECT and Achmea, the tribunals ignoring the applicability of the latter. Another example is the alleged non-applicability of Achmea in ICSID cases due to the principle of the irrevocability of consent under the ICSID Convention.

The reasons why intra-EU tribunals uphold their jurisdiction, even when they know that their awards cannot be enforced in the EU, are varied. The most compelling reason seems to be the one evoked by the Marfin v Cyprus Tribunal. Enforceability is a separate issue from jurisdiction. Thus, in the jurisdictional phase a tribunal should decide based on the law in front of it, and not whether the decision will be enforced or complied with.

The present situation, however, is clearly untenable. Even where some form of judicial dialogue exists, in the form of arbitral tribunals engaging with EU law and Achmea, the results are the same: intra-EU tribunals uphold their jurisdiction, render and award that is unenforceable in the EU, and investors then have to try enforcing the awards before third-country courts. One could argue that intra-EU tribunals could decline to exercise their jurisdiction in favour of EU courts (both national and EU level) as a sign of judicial comity. If this option is not suitable, then they could continue upholding their jurisdiction and then dismiss the case based on the need to ensure the effective administration of justice. The latter option could help intra-EU tribunals continue past practice relating to the effects of EU law on their jurisdiction - thus safeguarding the coherence of the investment law system - and it would also ensure that they would be perceived as a more legitimate system. Nevertheless, the likelihood that in practice they will adopt either of these approaches is very low. It seems that the only way the situation will be clarified is when the EU Member States terminate the intra-EU BITs with their sunset clauses and amend the ECT. However, these drastic measures will not affect pending cases. 
Annex 1. Post-Achmea, Concluded or Pending intra-EU Investment Arbitrations

\begin{tabular}{|c|c|c|c|c|c|c|}
\hline $\mathbf{N}$ & Short Name & Legal Ref. & IIA & Status & $\begin{array}{c}\text { Year of } \\
\text { Decision }\end{array}$ & $\begin{array}{c}\text { Achmea } \\
\text { discussed? }\end{array}$ \\
\hline 1 & Juvell \& Bithell v. Poland & ICC & CY-PO BIT & Concluded & 2019 & N/A \\
\hline 2 & Gavrilovic v Croatia & ICSID ARB/12/39 & AT-CR BIT & Concluded & 2018 & No \\
\hline 3 & Marfin v Cyprus & ICSID ARB/13/27 & CY-GR BIT & Concluded & 2018 & Yes \\
\hline 4 & RREEF v Spain & ICSID ARB/13/30 & ECT & Concluded & 2019 & Yes \\
\hline 5 & Antin v Spain & ICSID ARB/13/31 & ECT & Concluded & 2018 & No \\
\hline 6 & $U P$ and $C D v$ Hungary & ICSID ARB/13/35 & FR-HU BIT & Concluded & 2018 & Yes \\
\hline 7 & Masdar v Spain & ICSID ARB/14/1 & ECT & Concluded & 2018 & Yes \\
\hline 8 & NextEra v Spain & ICSID ARB/14/11 & ECT & Concluded & 2019 & N/A \\
\hline 9 & Sodexo v Spain & ICSID ARB/14/20 & FR-HU BIT & Concluded & 2019 & N/A \\
\hline 10 & Alpiq v. Romania & ICSID ARB/14/28 & RO-CH BIT, ECT & Concluded & 2018 & N/A \\
\hline 11 & B3 Croatian Courier v. Croatia & ICSID ARB/15/5 & CR-NL BIT & Concluded & 2019 & N/A \\
\hline 12 & ENGIE v. Hungary & ICSID ARB/16/14 & ECT & Concluded & 2018 & N/A \\
\hline 13 & A11Yv Czech Republic & ICSID UNCT/15/1 & UK-CZ BIT & Concluded & 2018 & No \\
\hline 14 & Darley Energy v. Poland (Darley I) & PCA & UK-PL BIT & Concluded & 2018 & N/A \\
\hline 15 & Antaris v Spain & PCA No. 2014-01 & DE-SK BIT, ECT & Concluded & 2018 & No \\
\hline 16 & Greentech v Italy & SCC 2015/095 & ECT & Concluded & 2018 & Yes \\
\hline 17 & Athena/Greentech v Spain & SCC 2015/150 & ECT & Concluded & 2018 & Yes \\
\hline 18 & Austrian Investors $v$. Poland & Ad hoc & AT-PO BIT & Pending & & N/A \\
\hline 19 & ICW v. Czech Republic & Ad hoc & CZ-UK BIT, ECT & Pending & & N/A \\
\hline 20 & Photovoltaik v. Czech Republic & Ad hoc & CZ-GE BIT, ECT & Pending & & N/A \\
\hline 21 & Voltaic v. Czech Republic & Ad hoc & CZ-GE BIT, ECT & Pending & & N/A \\
\hline 22 & Europa Nova v. Czech Republic & Ad hoc & CY-CZ BIT, ECT & Pending & & N/A \\
\hline 23 & Cypriot Investor v. Poland & Ad hoc & CY-PO BIT & Pending & & N/A \\
\hline 24 & Cordoba v. Spain & Ad hoc & ECT & Pending & & N/A \\
\hline 25 & AMF Aircraft v. Czech Republic & Ad hoc & CZ-GE BIT & Pending & & N/A \\
\hline
\end{tabular}




\begin{tabular}{|c|c|c|c|c|c|}
\hline 26 & EDF v. Spain & Ad hoc & ECT & Pending & N/A \\
\hline 27 & Honwood v. Poland (Darley II) & ICC & CY-PO BIT & Pending & N/A \\
\hline 28 & Vattenfall v. Germany (Vattenfall II) & ICSID ARB/12/12 & ECT & Pending & Yes \\
\hline 29 & Grassetto v. Slovenia & ICSID ARB/13/10 & SI-IT BIT & Pending & N/A \\
\hline 30 & EVN v. Bulgaria & ICSID ARB/13/17 & AU-BG BIT, ECT & Pending & N/A \\
\hline 31 & MOL v. Croatia & ICSID ARB/13/32 & ECT & Pending & N/A \\
\hline 32 & InfraRed v Spain & ICSID ARB/14/12 & ECT & Pending & N/A \\
\hline 33 & $\begin{array}{c}\text { Cyprus Popular Bank Public Co. } \\
\text { Ltd. v. Greece }\end{array}$ & ICSID ARB/14/16 & CY-GR BIT & Pending & N/A \\
\hline 34 & Renenergy v Spain & ICSID ARB/14/18 & ECT & Pending & N/A \\
\hline 35 & United Utilities v. Estonia & ICSID ARB/14/24 & NE-EST BIT & Pending & N/A \\
\hline 36 & Micula v. Romania (Micula II) & ICSID ARB/14/29 & SE-RO BIT & Pending & N/A \\
\hline 37 & $R W E v$ Spain & ICSID ARB/14/34 & ECT & Pending & N/A \\
\hline 38 & Stadtwerke v. Spain & ICSID ARB/15/1 & ECT & Pending & N/A \\
\hline 39 & 9REN v. Spain & ICSID ARB/15/15 & ECT & Pending & N/A \\
\hline 40 & KS Invest v Spain & ICSID ARB/15/15 & ECT & Pending & N/A \\
\hline 41 & BayWa r.e. v Spain & ICSID ARB/15/16 & ECT & Pending & N/A \\
\hline 42 & Cube Infrastructure v. Spain & ICSID ARB/15/20 & ECT & Pending & N/A \\
\hline 43 & Kruck v Spain & ICSID ARB/15/25 & ECT & Pending & N/A \\
\hline 44 & JGC v. Spain & ICSID ARB/15/27 & ECT & Pending & N/A \\
\hline 45 & Gabriel Resources v. Romania & ICSID ARB/15/31 & $\begin{array}{l}\text { CA-RO BIT; } \\
\text { UK-RO BIT }\end{array}$ & Pending & Yes \\
\hline 46 & Cavalum v. Spain & ICSID ARB/15/34 & ECT & Pending & N/A \\
\hline 47 & EON v. Spain & ICSID ARB/15/35 & ECT & Pending & N/A \\
\hline 48 & OperaFund v. Spain & ICSID ARB/15/36 & ECT & Pending & N/A \\
\hline 49 & Silver Ridge v. Italy & ICSID ARB/15/37 & ECT & Pending & N/A \\
\hline 50 & SolEs v. Spain & ICSID ARB/15/38 & ECT & Pending & N/A \\
\hline 51 & STEAG v. Spain & ICSID ARB/15/4 & ECT & Pending & N/A \\
\hline 52 & Belenergia v. Italy & ICSID ARB/15/40 & ECT & Pending & N/A \\
\hline
\end{tabular}




\begin{tabular}{|c|c|c|c|c|c|}
\hline 53 & Hydro Energy v. Spain & ICSID ARB/15/42 & ECT & Pending & N/A \\
\hline 54 & Watkins v. Spain & ICSID ARB/15/44 & ECT & Pending & N/A \\
\hline 55 & Landesbank v. Spain & ICSID ARB/15/45 & ECT & Pending & N/A \\
\hline 56 & Adamakopoulos v. Cyprus & ICSID ARB/15/49 & $\begin{array}{l}\text { CY-GR BIT; } \\
\text { BLEU-GR BIT }\end{array}$ & Pending & N/A \\
\hline 57 & Eskosol v. Italy & ICSID ARB/15/50 & ECT & Pending & N/A \\
\hline 58 & Sun-Flower v. Spain & ICSID ARB/16/17 & ECT & Pending & N/A \\
\hline 59 & Infracapital v. Spain & ICSID ARB/16/18 & ECT & Pending & N/A \\
\hline 60 & Nova Group v. Romania & ICSID ARB/16/19 & NL-RO BIT & Pending & N/A \\
\hline 61 & Sevilla v. Spain & ICSID ARB/16/27 & ECT & Pending & N/A \\
\hline 62 & Amlyn Holding v. Croatia & ICSID ARB/16/28 & ECT & Pending & N/A \\
\hline 63 & Veolia v. Lithuania & ICSID ARB/16/3 & FR-LV BIT & Pending & N/A \\
\hline 64 & UniCredit Bank v. Croatia & ICSID ARB/16/31 & AT-CR BIT & Pending & N/A \\
\hline 65 & VC Holding v. Italy & ICSID ARB/16/39 & ECT & Pending & N/A \\
\hline 66 & Eurus v. Spain & ICSID ARB/16/4 & ECT & Pending & N/A \\
\hline 67 & ESPF v. Italy & ICSID ARB/16/5 & ECT & Pending & N/A \\
\hline 68 & Rockhopper v. Italy & ICSID ARB/17/14 & ECT & Pending & N/A \\
\hline 69 & Portigon v. Spain & ICSID ARB/17/15 & ECT & Pending & N/A \\
\hline 70 & Magyar Farming v. Hungary & ICSID ARB/17/27 & UK-HU BIT & Pending & N/A \\
\hline 71 & Elitech v. Croatia & ICSID ARB/17/32 & CR-NL BIT & Pending & N/A \\
\hline 72 & Raiffeisen Bank v. Croatia & ICSID ARB/17/34 & AT-CR BIT & Pending & N/A \\
\hline 73 & Addiko Bank v. Croatia & ICSID ARB/17/37 & AT-CR BIT & Pending & N/A \\
\hline 74 & Bank of Cyprus v. Greece & ICSID ARB/17/4 & CY-GR BIT & Pending & N/A \\
\hline 75 & $\begin{array}{c}\text { Bank of Cyprus Public Company } \\
\text { Limited v. Greece }\end{array}$ & ICSID ARB/17/4 & CY-GR BIT & Pending & N/A \\
\hline 76 & DCM Energy v. Spain & ICSID ARB/17/41 & ECT & Pending & N/A \\
\hline 77 & Norvik Banka v. Latvia & ICSID ARB/17/47 & LT-UK BIT & Pending & N/A \\
\hline 78 & Erste Group v. Croatia & ICSID ARB/17/49 & AT-CR BIT & Pending & N/A \\
\hline 79 & LSG Building Solutions v. Romania & ICSID ARB/18/19 & ECT & Pending & N/A \\
\hline 80 & Veolia v. Italy & ICSID ARB/18/20 & ECT & Pending & N/A \\
\hline 81 & Bladon v. Romania & ICSID ARB/18/30 & CY-RO BIT & Pending & N/A \\
\hline
\end{tabular}




\begin{tabular}{|c|c|c|c|c|c|}
\hline 82 & Alverley Investments v. Romania & ICSID ARB/18/30 & CY-RO BIT & Pending & N/A \\
\hline 83 & EBL v. Spain & ICSID ARB/18/42 & ECT & Pending & N/A \\
\hline 84 & European Solar v. Spain & ICSID ARB/18/45 & ECT & Pending & N/A \\
\hline 85 & Canepa v. Spain & ICSID ARB/19/4 & ECT & Pending & N/A \\
\hline 86 & WCV v. Czech Republic & PCA & CY-CZ BIT & Pending & N/A \\
\hline 87 & CSP Equity v. Spain & PCA & ECT & Pending & N/A \\
\hline 88 & PV Investors $v$ Spain & PCA No. 2012-14 & ECT & Pending & N/A \\
\hline 89 & Natland v Czech Republic & PCA No. 2013-35 & $\begin{array}{l}\text { CZ-NL BIT; CY-CZ BIT; } \\
\text { BLEU - CZ BIT; ECT }\end{array}$ & Pending & N/A \\
\hline 90 & Slot $v$ Poland & PCA No. 2017-10 & CZ-PO BIT & Pending & N/A \\
\hline 91 & $\begin{array}{l}\text { Fynerdale Holdings v. Czech } \\
\text { Republic }\end{array}$ & PCA No. 2018-18 & CZ-NL BIT & Pending & N/A \\
\hline 92 & Alten v. Spain & $\mathrm{SCC}$ & ECT & Pending & N/A \\
\hline 93 & CEF v. Italy & $\mathrm{SCC}$ & ECT & Pending & N/A \\
\hline 94 & Green Power v. Spain & $\mathrm{SCC}$ & ECT & Pending & N/A \\
\hline 95 & Sun Reserve v. Italy & $\mathrm{SCC}$ & ECT & Pending & N/A \\
\hline 96 & FREIF Eurowind v. Spain & $\mathrm{SCC}$ & ECT & Pending & N/A \\
\hline 97 & Triodos v. Spain & SCC & ECT & Pending & N/A \\
\hline 98 & Griffin v. Poland & SCC No. 2014/168 & BLEU-PO BIT & Pending & N/A \\
\hline
\end{tabular}


Annex 2. Pre-Achmea, Concluded intra-EU Investment Arbitrations

\begin{tabular}{|c|c|c|c|c|c|}
\hline $\mathbf{N}$ & Short Name & Legal Ref. & IIA & Status & Year of Decision \\
\hline 1 & Eastern Sugar $v$ Czech & SCC 088/2004 & CZ-NL BIT & Concluded & 2004 \\
\hline 2 & AES $v$ Hungary II & ICSID ARB/07/22 & ECT & Concluded & 2010 \\
\hline 3 & Vöcklinghaus $v$. Czech Republic & Ad hoc & CZ-GE BIT & Concluded & 2011 \\
\hline 4 & Achmea $v$. Slovakia & PCA 2008-13 & NL-SK BIT & Concluded & 2012 \\
\hline 5 & Electrabel $v$ Hungary & ICSID ARB 07/19 & ECT & Concluded & 2012 \\
\hline 6 & Euram $v$ Slovakia & PCA 2010-17 & AT-SK BIT & Concluded & 2012 \\
\hline 7 & Servier $v$ Poland & PCA & FR-PO BIT & Concluded & 2012 \\
\hline 8 & ECE $v$ Czech Republic & PCA Case No. 2010-5 & CZ-GE BIT & Concluded & 2013 \\
\hline 9 & Micula $v$ Romania $(I)$ & ICSID ARB/05/20 & SE-RO BIT & Concluded & 2013 \\
\hline 10 & Anglia and Busta $v$ Czech Republic & SCC & CZ-UK BIT & Concluded & 2014 \\
\hline 11 & Enkev Beheer $v$ Poland & PCA Case No. 2013-01 & NL-PO BIT & Concluded & 2014 \\
\hline 12 & Forminster $v$ Czech Republic & Ad hoc & CY-CZ BIT & Concluded & 2014 \\
\hline 13 & Charanne $v$ Spain & SCC 062/2012 & ECT & Concluded & 2016 \\
\hline 14 & Isolux $v$ Spain & SCC V2013/153 & ECT & Concluded & 2016 \\
\hline 15 & Seventhsun $v$ Poland & SCC & CY-PO BIT & Concluded & 2016 \\
\hline 16 & Busta $v$ Czech Republic & SCC Case No. 2015/014 & CZ-UK BIT & Concluded & 2017 \\
\hline 17 & Eiser $v$ Spain & ICSID ARB/13/36 & ECT & Concluded & 2017 \\
\hline 18 & Energija $v$ Latvia & ICSID ARB/12/33 & LV-LT BIT & Concluded & 2017 \\
\hline 19 & Horthel $v$ Poland & PCA Case No. 2014-31 & NL-PO BIT & Concluded & 2017 \\
\hline 20 & JSW $v$ Czech Republic & PCA Case No. 2014-03 & CZ-GE BIT & Concluded & 2017 \\
\hline 21 & WNC $v$ Czech Republic & PCA Case No. 2014-34 & CZ-UK BIT & Concluded & 2017 \\
\hline 22 & Novenergia $v$ Spain & SCC Arbitration 2015/063 & ECT & Concluded & 2018 \\
\hline & & & & \\
\hline
\end{tabular}

